\title{
Special annotations
}

\section{Schönlein-Henoch syndrome}

This characteristic syndrome of skin, gastrointestinal, and joint disorders has fascinated many distinguished physicians. Schönlein ${ }^{1}$ in Berlin described the association of arthritis and purpuric rash in 1832 and it was one of his former students, Eduard Henoch, ${ }^{2}$ who nearly 40 years later described the association of gastrointestinal symptoms and a similar rash. Professor Henoch was one of the first German physicians to specialise in paediatrics. He maintained his interest in the syndrome throughout his life and, at age 90 , shortly before his death he recorded the important association of serious kidney disease. ${ }^{3}$ Although Schönlein and Henoch gave their names to its eponymous title it does seem that other distinguished physicians had noticed the condition earlier. There is an excellent description by Heberden in 1801, and another by Willan (1808) in his book on cutaneous diseases. ${ }^{4,5}$ At the turn of the century William Osler devoted many of his later years to study of the condition and his concept of 'anaphylactoid purpura' although confusing in some ways did draw a useful comparison between the systemic reaction of serum sickness and the illness of Schönlein-Henoch syndrome. ${ }^{5}$ Douglas Gairdner from 'the Department of Child Health, Kings College, University of Durham' completed a paper on the syndrome in 1947 which was a worthy successor to its illustrious predecessors and in many ways it is still the most detailed and accurate description of the syndrome in the English language. His personal observations were based on only 12 cases, but the scholarship, research, and thoughtfulness with which they were presented makes it a more useful paper than many of its successors. It is a long paper, 30 pages, which is perhaps why he published it in the Quarterly Journal of Medicine. It might have received wider paediatric acclaim had it been published elsewhere. The description of the skin lesions is excellent and contains many of the points usually overlooked in subsequent publications, but which nevertheless are important diagnostic features, for instance, the way in which the rash apart from having the well known topographical distribution also has a predilection for areas of pressure, with 'a striking delay of from 12-24 hours . . . the skin creases beneath the sphygmomanometer cuff become outlined on the day after a blood pressure reading'. The rash is frequently found in bands on the skin near the top of tight socks or at the waist. ${ }^{6}$ Gairdner emphasised the way in which the crops of rash could come and go for a very long time; one child whom he studied was still having crops 2 years after onset. His paper also contained what $I$ think is the first description of the variation of the rash that is seen in young preschool children. They often have a more obviously urticarial rash with big weals which later may become purpuric. Oedema of the scalp and face and the dorsum of the hands and feet is common. The only feature he did not mention and which does cause some confusion is the subcutaneous bleeding that may occur almost anywhere, for instance, bleeding into the eyelids and conjunctiva or bleeding into the scrotum mimicking torsion of the testicle.

Further study of the condition has led to the realisation that a variety of other manifestations can occur with the syndrome; nose bleeds may be severe and there may be bleeding into the calf which simulates a deep vein thrombosis; convulsions, encephalopathy, facial palsy, and chorea occasionally occur. ${ }^{\text {? }}$

Gairdner's article drew attention to the spectrum of disease ranging from rheumatic fever through Schönlein-Henoch syndrome to polyarteritis nodosa. At the time his article was written streptococcal infection was common and serious in Britain. It is much less common now and less severe. No longer is the streptococcus the commonest antecedent of Schönlein-Henoch syndrome. A variety of infective agents and occurrences have been linked with the syndrome. They range from specific infecting organisms such as Mycoplasma pneumoniae ${ }^{8}$ and varicella ${ }^{9}$ to food allergens, ${ }^{10}$ drugs, ${ }^{11,12}$ insect bites, ${ }^{13}$ and exposure to cold. ${ }^{14}$ The same syndrome can result from a variety of different provocations. Gairdner's suggestion of a link between polyarteritis nodosa and Schönlein-Henoch syndrome is one with which I agree. Polyarteritis nodosa is extremely rare in childhood but occurs either in the infant or, much later, in the teenage childhood. SchönleinHenoch syndrome is not seen in infants, is most common in young children, and then becomes 
uncommon in teenage children and adults. It is almost as if the syndrome occurs in childhood instead of polyarteritis nodosa.

Gairdner said 'No treatment has been proved to have any effect upon the course of the illness'; sadly that remark is still true today. ${ }^{6}$ Although there is widespread agreement that corticosteroids can have a beneficial effect on the alimentary symptoms, ${ }^{15}$ no drug or course of management has been shown to affect the occurrence or recurrence of the disease or its progression. Gairdner, way ahead of his time, decried the use of bed rest for the condition pointing out that it did not seem to influence the course or the prognosis. (The impact on his readers of this splendid cri de coeur must have been lessened somewhat by a striking photograph a few pages later showing 'gross purpuric and necrotic lesions on the buttocks, the curved marks corresponding to the edge of the bed pan'.)

Blood-stained urine in a child with the syndrome was recognised by Heberden in $1801 .{ }^{4}$ Gairdner was one of the first to suggest that the renal lesion was the most serious component of the syndrome. Nowadays it is the glomerulonephritis which is almost entirely responsible for the $1-3 \%$ mortality rate of Schönlein-Henoch syndrome. Of Gairdner's 12 patients, one died of renal failure and another 2 had chronic renal insufficiency. In recent years much information has been obtained about SchönleinHenoch nephritis from several large surveys. ${ }^{15,16,17 .}$ $18,19,20$ The proportion of patients reported to have renal involvement varies between 20 and $100 \%$ depending upon the criteria for 'renal involvement'. Raised red cell excretion rates in the urine have been found in all children with the syndrome ${ }^{19}$ and an abnormal renal histological picture has been reported in children with Schönlein-Henoch syndrome who had normal urine on routine testing. ${ }^{21}$ On routine testing between 30 and $70 \%$ will have albuminuria and microscopic haematuria and another $20-30 \%$ have macroscopic haematuria. Although the renal illness may be most severe in the early stages of the disease a remarkable degree of recovery is possible. Those who have merely microscopic haematuria are likely to be completely normal 10 years later. The large group who have symptomless haematuria and proteinuria on the whole do well although up to $20 \%$ may develop permanent renal damage. The small number of children who have acute nephritic syndrome and a nephrotic syndrome early in the course of the illness are those who have the most serious disease. Up to half of them subsequently develop renal insufficiency, but even for that group nearly half appear in good health with reasonable renal function $10^{\text {\} } \text { years }$ later. ${ }^{22,23}$ The pathology of the renal lesion is well studied and described but does not as yet shed much light on the aetiology.7, 24 Apart from the diffuse mesangial proliferation with pronounced focal variation that is visible on light microscopy, the outstanding finding is $\operatorname{IgA}$ deposition in the glomerular mesangium and also occasionally spread along the basement membrane in severe cases. ${ }^{25}$ Its similarity to the immunofluorescent appearance of Berger's disease (clinically one of the varieties of 'recurrent haematuria of childhood') raises the question whether Berger's disease is a type of Schönlein-Henoch syndrome; after all we frequently diagnose the syndrome in the absence of involvement of joints, gut, or kidneys, but we never diagnose it in the absence of skin involvement because that is the pathognomic sign. If we had a reliable test for the syndrome we might be diagnosing it in many children who did not have the characteristic rash. Perhaps IgA deposition in the glomerulus and also in blood vessels of the skin is the most important feature.

Schönlein-Henoch nephritis accounts for about $15 \%$ of children who are put on dialysis in Europe because of end-stage renal failure. It is important that either prevention or effective treatment is found. So far there is no evidence that any drug affects the course of the renal lesion although there is a shortage of adequately controlled trials and the results of the trial of cyclophosphamide by the International Study of Kidney Disease in Childhood are awaited with interest.

The prevention and management of SchönleinHenoch syndrome has not advanced as far as Douglas Gairdner must have hoped when he wrote his important paper in 1947. However, it is worth remembering that Sir William Osler published his most useful contribution on the syndrome after his retirement, and that Henoch who was responsible for clearly defining the renal involvement that accompanied the syndrome published that paper in his 90 th year. At that rate I shall expect the definitive paper on the cause and prevention of SchönleinHenoch syndrome to be written by Douglas Gairdner somewhere around the year 2005, and trust that he will publish it in the'Archives of Disease in Childhood and not in the Quarterly Journal of Medicine.

\section{References}

${ }^{1}$ Schönlein, J. L. (1832). Allgemeine und specielle Pathologie und Therapie, p. 41. Etlinger: Würzburg.

${ }^{2}$ Henoch, E. (1868). Verhandlungen ärztlicher Gesellschaffen. Berliner klinische Wochenschrift, 5, 517.

${ }^{3}$ Henoch, E. (1895). Neunter Abschnitt. III. Die hämorrhagische Diathese-Purpura. In Vorlesungen über Kinderkrankheiten, p. 847. Hirschwald: Berlin.

${ }^{4}$ Heberden, W. (1801). Commentarii di Morborium-Historia et Curatione, chapter 78. Payne: London. 
${ }^{5}$ Willan, R. (1808). On Cutaneous Disease. Johnson: London. ${ }^{6}$ Gairdner, D. (1948). The Schönlein-Henoch syndrome (anaphylactoid purpura). Quarterly Journal of Medicine, 17, 95-122.

${ }^{7}$ Meadow, R. (1978). Schönlein-Henoch syndrome. In Paediatric Kidney Disease, chapter 61. Edited by_C. M. Edelman. Little Brown: Boston.

${ }^{8}$ Liew, S. W., and Kessel, I. (1974). Letter: Mycoplasmal pneumonia preceding Henoch-Schönlein purpura. Archives of Disease in Childhood, 49, 912.

${ }^{9}$ Pedersen, F. K., and Petersen, E. A. (1975). Varicella followed by glomerulonephritis. Acta paediatrica Scandinavica, 64, 886-890.

${ }^{10}$ Alexander, H. L., and Eyermann, C. H. (1927). Food allergy in Henoch's purpura. Archives of Dermatology and Syphilology, 16, 322-327.

${ }^{11}$ Ackroyd, M. B. (1953). Allergic purpura, including purpura due to foods, drugs, and infections. American Journal of Medicine, 14, 605-632.

${ }^{12}$ Handa, S. P. (1972). The Schönlein-Henoch syndrome. Glomerulonephritis following erythromycin. Southern Medical Journal, 65, 917-920.

${ }^{13}$ Burke, D. M., and Jellinek, J. L. (1954). Nearly fatal case of Schönlein-Henoch syndrome following insect bite. American Journal of Diseases of Children, 88, 772-774.

${ }^{14}$ Rogers, P. W., Bunn, S. M., Jr, Kurtzman, M. C., and White, M. C. (1971). Schönlein-Henoch syndrome associated with exposure to cold. Archives of Internal Medicine, 128, 782-786.

${ }^{15}$ Allen, D. M., Diamond, L. K., and Howell, D. A. (1960). Anaphylactoid purpura in children (Schönlein-Henoch syndrome). American Journal of Diseases of Children, 99, 833-854.

${ }^{16}$ Hurley, R. M., and Drummond, K. N. (1972). Anaphylactoid purpura nephritis: clinicopathological correlations. Journal of Pediatrics, 81, 904-911.

${ }^{17}$ Koskimies, O., Rapola, J., Sanilakt, E., and Vilska, J. (1974). Renal involvement in Schönlein-Henoch purpura. Acta paediatrica Scandinavica, 63, 357-363.
${ }^{18}$ Marchal, A., Bost, M., Dieterlen, N., Rossignol, A. M., Gout, J. P., and Beaudoing, A. (1974). Syndrome de Schönlein-Henoch de l'enfant'. Annales de pédiatrie, 21, 379-392.

${ }^{19}$ Meadow, S. R., Glasgow, E. F., White, R. H. R., Moncrieff, M. W., Cameron, J. S., and Ogg, C. S. (1972). SchönleinHenoch nephritis. Quarterly Journal of Medicine, 41, 241-258.

${ }^{20}$ Potanin, N. V. (1970). Klinická charakteristika postiženi lędrin pri chorobě Schönleinově-Henochově u děti. Československá pediatrie, 25, 147-150.

${ }^{21}$ Greifer, I., Bernstein, J., Kikkawa, Y., and Edelmann, C. M., Jr (1966). Histologic evidence of nephritis in patients with Henoch-Schönlein syndrome without clinical evidence of renal disease. In the Proceedings of the American Society of Nephrology.

${ }^{22}$ Counahan, R., Winterborn, M. H., White, R. H. R., Heaton, J., Meadow, S. R., Bluett, N. H., Swetschin, H., Cameron, J. S., and Chantler, C. (1977). Prognosis of Schönlein-Henoch nephritis in children. British Medical Journal, 2, 11-14.

${ }^{23}$ Meadow, S. R. (1978). The prognosis of Henoch-Schönlein nephritis. Clinical Nephrology, 9, 87-90.

${ }^{24}$ Habib, R., and Levy, M. (1972). Les néphropathies du purpura rhumatoïde chez l'enfant. Archives françaises de pédiatrie, 29, 305-324.

${ }^{25}$ Heaton, J. M., Turner, D. R., and Cameron, J. S. (1977). Localisation of glomerular 'deposits' in Henoch-Schönlein nephritis. Histopathology, 1, 93-104.

Roy Meadow

University of Leeds, Department of Paediatrics and Child Health, 27 Blundell Street, Leeds LS1 3ET 